\title{
CHARACTERIZATION OF ALKALINE LIPASE FROM FUSARIUM OXYSPORUM AND THE EFFECT OF DIFFERENT SURFACTANTS AND DETERGENTS ON THE ENZYME ACTIVITY
}

\author{
Janaina Nicanuzia dos Prazeres*; Juliana Aparecida Bortollotti Cruz; Gláucia Maria Pastore
}

Departamento de Ciência de Alimentos, Faculdade de Engenharia de Alimentos, Unicamp, Campinas, São Paulo, Brazil

Submitted: March 08, 2006; Returned to authors for corrections: June 01, 2006; Approved: October 10, 2006

\begin{abstract}
Nowadays, there is a tendency of use of low temperature in laundry cleaning for both environmental and economical reasons, which makes the use of enzymes in detergent products indispensable. Since lipases are efficient catalyst both in solution and at the water-liquid interface, they are potentially suitable for lipid stain removal applications in industrial laundry and household detergents. The effect of different commercial detergents and surfactants on enzymatic activity of lipase from Fusarium oxysporum was observed through $p$-nitrophenylpalmitate ( $p$ NPP) assay. The enzyme was compatible with various ionic and non-ionic surfactants as well as commercial detergents. Lipase activity was strongly inhibited by Sodium Dodecyl Sulphate (SDS), but not by Triton X-100 and Triton X-114. The best assay conditions observed for this lipase were $\mathrm{pH} 8.0$ and $50^{\circ} \mathrm{C}$. The enzyme was stable at alkaline $\mathrm{pH}$ and remained $93 \%$ of residual activity during $1 \mathrm{~h}$ incubation at $60^{\circ} \mathrm{C}$. The highest lipase activity was measured with triglycerides of middle and long chain fatty acids $\left(\mathrm{C}_{8}-\mathrm{C}_{18}\right)$. This enzyme showed a variable specifity/hydrolytic activity towards various fats and oils. All these properties and its resistance towards various surfactants and tolerance to commercial detergents make this lipase a potential additive for detergent formulation.
\end{abstract}

Key words: alkaline lipase, fusarium oxysporum, surfactants, detergents

\section{INTRODUCTION}

Lipases (triacylglycerol acylhidrolases, EC 3.1.1.3) hydrolyze tri-, di- and monoglycerides at an oil-water interface where the lipases activities are greatly increased by a mechanism of interfacial activation $(5,8)$. The majority of lipases exhibit a high activity toward lipids with fatty acid residues of $\mathrm{C}_{8}$ to $\mathrm{C}_{18}$ chain length (15). The lipase used in each application is selected based on its substrate specificity such as fatty acid, alcohol, position (regio-) and stereospecificity, as well as temperature and $\mathrm{pH}$ stability (17).

Microbial lipases have already established their vast potential regarding to their usage in different industries. The interest in microbial lipase production has increased in the last decades, because of its large potential in industrial applications as additives for foods (flavor modification), fine chemicals (synthesis of esters), waste water treatment (decomposition and removal of oil substances), cosmetics (removal of lipids), pharmaceuticals (digestion of oil and fats in foods), leather (removal of lipids from animal skins) and medical (blood triglyceride assay) $(2,4,9,13)$. However, the biggest market of their use is in the detergent formulation $(7,16)$. Regarding detergents applications, new challenges for lipases producers can be pointed $(7,18,19)$ : (1) the high variation in the triglyceride content of fat stains, requiring lipases with low substrate specificity; (2) the relatively harsh washing conditions $\left(\mathrm{pH} 10-11\right.$ and $30-60^{\circ} \mathrm{C}$ ), requiring stable enzymes; and (3) the effects of chemical denaturation and/or proteolytic degradation caused by detergents additives such as surfactant linear alkyl benzene sulfonate (LAS) and proteases. The functional importance of lipases in the detergent industry is related to the removal of fatty residues in laundry, dishwashers as well as for cleaning of clogged drains.

*Corresponding Author. Mailing address: Rua Jorge Krug, 178, Apto. 45 Vila Itapura 13023-210 Campinas, São Paulo - Brasil. Tel.: (19) 3788-3887.

E-mail: nicanuzia@yahoo.com 
The purposes of the present study were to characterize the alkaline lipase from Fusarium oxysporum with respect to optimal $\mathrm{pH}$ and temperature as well as stability, and evaluate the effect of several detergents and surfactants on the enzyme activity.

\section{MATERIALAND METHODS}

\section{Strain}

Fusarium oxysporum was isolated from Brazilian Northeast fruits (Maceió, AL, and Aracaju, SE).

\section{Chemicals}

Olive oil used for lipase assay was from Azeite "Gallo", Victor Guedes, Ind. e Com., S.A., (Portugal). All analytical chemicals and media components used were of highest purity grade available commercially. All other oils and commercial detergents used were purchased locally.

\section{Lipase production}

Fusarium oxysporum was cultivated for $96 \mathrm{~h}$, at $30^{\circ} \mathrm{C}$ in a medium consisting of (w/v): glucose $1.0 \%$; peptone $0.3 \%$; yeast extract $0.2 \% ; \mathrm{K}_{2} \mathrm{HPO}_{4} 0.2 \% ; \mathrm{MgSO}_{4} .7 \mathrm{H}_{2} \mathrm{O} 0.1 \% ; \mathrm{Na}_{2} \mathrm{CO}_{3} 0.1 \%$; and agar $2.0 \%$. After that, it was transferred to a liquid medium contained (w/v): olive oil $1.0 \%$; peptone $1.5 \%$; yeast extract $0.5 \% ; \mathrm{KH}_{2} \mathrm{PO}_{4} 0.3 \% ; \mathrm{MgSO}_{4} .7 \mathrm{H}_{2} \mathrm{O} 0.04 \%$, pH 6.0. Fermentation was carried out at $30^{\circ} \mathrm{C}$ under $160 \mathrm{rpm}$ in shaker. After $24 \mathrm{~h}, 1 \mathrm{~mL}$ of the culture medium was transferred to a fresh medium and incubated for more $48 \mathrm{~h}$. The fermented medium was chilled rapidly to $4^{\circ} \mathrm{C}$ and the cells were removed by filtration. The supernatant was fractionated with ammonium sulfate to $70 \%$ saturation. After centrifugation, the precipitated was dialyzed against water at $4^{\circ} \mathrm{C}$ and freeze-dried (Lin et al., modified (10)).

\section{Assay of Lipase}

All the experiments were performed in triplicate and the standard derivation calculated.

Assay using olive oil as substrate: Lipase activity was determined by titrimetry using olive oil emulsion which was prepared by mixing $25 \mathrm{~mL}$ of olive oil and $75 \mathrm{~mL}$ of $7 \%$ arabic gum solution in a homogenizer for $2 \mathrm{~min}$. The reaction mixture containing $5 \mathrm{~mL}$ of olive oil emulsion, $4 \mathrm{~mL}$ of $50 \mathrm{mM}$ Tris- $\mathrm{HCl}$ buffer, $\mathrm{pH} 8.0,1 \mathrm{~mL}$ of $110 \mathrm{mM} \mathrm{CaCl}_{2}$ and $1 \mathrm{~mL}$ of enzyme $(5 \mathrm{mg} /$ $\mathrm{mL}$ ) was incubated at $50^{\circ} \mathrm{C}$ for 30 min under orbital shaking at $160 \mathrm{rpm}$. The reaction was immediately stopped after the incubation period by the addition of $15 \mathrm{~mL}$ acetone:ethanol mixture $(1: 1 \mathrm{v} / \mathrm{v})$, and the released free fatty acids were titrated with $50 \mathrm{mM} \mathrm{NaOH}$. One unit (U) of lipase activity was defined as the amount that released $1 \mu \mathrm{mol}$ of fatty acid per min [11].

Assay using different fats and oils as substrates: $2 \%(\mathrm{w} / \mathrm{v})$ of fats and oils (olive oil, soybean oil, sunflower oil, corn oil, chicken oil and milk cream) and $100 \mathrm{mM}$ of triglycerides (triacetin, tributyrin, tricaprylin, trilaurin and triolein) were individually added to the reaction mixture containing $4 \mathrm{~mL}$ of $50 \mathrm{mM}$ Tris$\mathrm{HCl}$ buffer, $\mathrm{pH} 8.0,1 \mathrm{~mL}$ of $110 \mathrm{mMCaCl}_{2}$ and $1 \mathrm{~mL}$ of enzyme (5 $\mathrm{mg} / \mathrm{mL}$ ). After $30 \mathrm{~min}$ of incubation at $50^{\circ} \mathrm{C}$ with orbital shaking at $160 \mathrm{rpm}$, the reaction was immediately stopped by the addition of $15 \mathrm{~mL}$ acetone:ethanol mixture $(1: 1 \mathrm{v} / \mathrm{v})$, and the released free fatty acids were titrated with $50 \mathrm{mM} \mathrm{NaOH}$. One unit (U) of lipase activity was defined as the amount that released $1 \mu \mathrm{mol}$ of fatty acid per min.

Assay using $p$-nitrophenylpalmitate ( $p$ NPP) as substrate: The activity was assayed with reaction mixture, in a final volume of $1 \mathrm{~mL}$, containing $40 \mathrm{mM}$ Tris- $\mathrm{HCl}$ buffer (pH 8.0), 20 $\mathrm{mM} p \mathrm{NPP}$, as substrate, and $25 \mu \mathrm{L}$ of enzyme $(5 \mathrm{mg} / \mathrm{mL})$. After 10 min of incubation at $40^{\circ} \mathrm{C}$, the reaction was stopped by the addition of $2 \mathrm{~mL}$ of ethanol $96 \%$, and the $p$-nitrophenol released was monitored spectrophotometrically at $420 \mathrm{~nm}$, using a standard curve. One lipase unit (U) was defined as the amount of enzyme that released $1 \mu \mathrm{mol} p$-nitrophenol per minute.

\section{Effect of pH on activity and stability}

The $\mathrm{pH}$ effect on activity and stability profiles were studied by olive oil assay in a pH range of 3.5-11.0 using different buffers at $50 \mathrm{mM}$ concentration. For stability, $1 \mathrm{~mL}$ of enzyme $(5 \mathrm{mg} / \mathrm{mL})$ was mixed with $1 \mathrm{~mL}$ of respective buffer and incubated for $24 \mathrm{~h}$ at $4^{\circ} \mathrm{C}$. After that, the assay was performed as described for olive oil assay.

\section{Effect of temperature on activity and stability}

Temperature effect on lipase activity was studied by carrying out the enzyme reaction at different temperatures in the range of $10-70^{\circ} \mathrm{C}$ at $\mathrm{pH} 8.0$ using Tris-HCl buffer $(50 \mathrm{mM})$. The thermostability of lipase was tested by pre-incubating the enzyme $(5 \mathrm{mg} / \mathrm{mL})$ at different temperatures ranging from 30 to $80^{\circ} \mathrm{C}$ for $1 \mathrm{~h}$. After that, the assay was performed as described for olive oil assay.

\section{Effects of surfactants and commercial detergents on enzyme stability}

Effects of surfactants (Tween 20, Tween 40, Tween 80, Triton X-100, Triton X-114, Sodium Dodecyl Sulphate (SDS) and surfactin from Bacillus subtilis (12)) and commercial detergents (Omo, Vida Plus, Tixan, Ace, Ariel, Brilhante, Surf and Revel) on enzyme stability were determined toward $p$-nitrophenylpalmitate $(p \mathrm{NPP})$ assay. $50 \mu \mathrm{L}$ of enzyme sample $(5 \mathrm{mg} / \mathrm{mL})$ were incubated in $50 \mu \mathrm{L}$ of surfactants and commercial detergents (solution of $0.1,1.0$ and $10.0 \% \mathrm{w} / \mathrm{v})$ for $1 \mathrm{~h}$ at room temperature $\left(30 \pm 2^{\circ} \mathrm{C}\right)$ and the residual activity was determined at $\mathrm{pH} 8.0$ and $40^{\circ} \mathrm{C}$ for $10 \mathrm{~min}$, using $p$-NPP as substrate as described for $p$ nitrophenypamitate assay. 


\section{RESULTS AND DISCUSSION}

In the present work alkaline lipase was most active in $\mathrm{pH}$ range between 7.0 and 9.5. This enzyme was found to be stable in $\mathrm{pH} 7.0$ to 9.0 , and it kept around $45 \%$ activity after $24 \mathrm{~h}$ incubation in buffer of $\mathrm{pH} 11.0$, at $4^{\circ} \mathrm{C}$ (Fig. 1). The lipase from $F$. oxysporum f. sp. lini was stable in $\mathrm{pH}$ range 6.0-7.0 and had optimum activity at $\mathrm{pH} 7.0(6)$, while this enzyme showed to be more stable in alkaline $\mathrm{pH}$. On another hand, some lipases from Baccilus thermoleovorans were found to be most active at $\mathrm{pH}$ 9.0-10.0 and stable in a broad range of $\mathrm{pH}$ values 5.0-11.0,

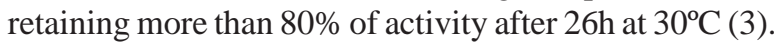

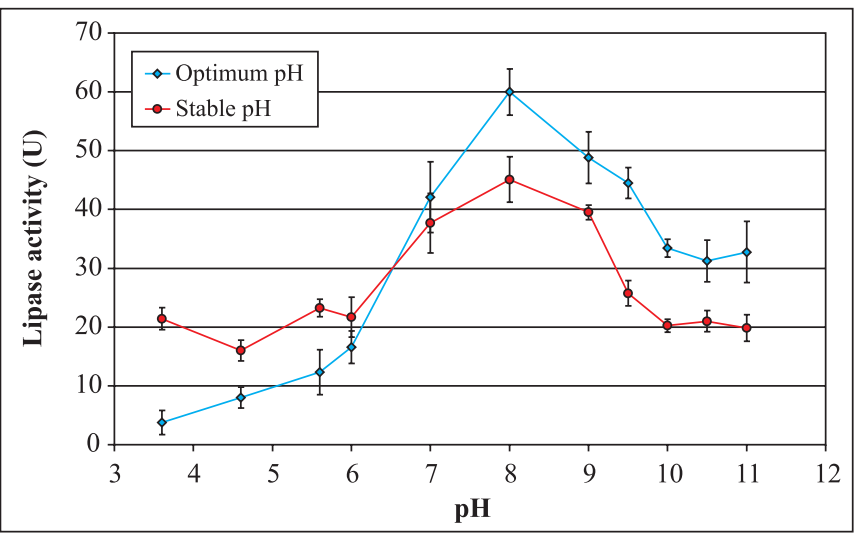

Figure 1. Effects of $\mathrm{pH}$ on alkaline lipase activity and stability. The experiments were performed in triplicate and bars represent the standard derivation.

The optimum reaction temperature was $50^{\circ} \mathrm{C}$. Thermal stability was investigated by incubating the enzyme at various temperatures for $1 \mathrm{~h}$. The enzyme showed great stability up to $60^{\circ} \mathrm{C}$ (Fig. 2). Compared to higher thermal stability at $50^{\circ} \mathrm{C}$, this lipase kept $93 \%$ activity at $60^{\circ} \mathrm{C}$. These results show that this enzyme is more stable than lipase from $F$. oxysporum $\mathrm{f}$. sp. lini which activity was reduced by about $50 \%$ at $60^{\circ} \mathrm{C}$ when the enzyme solution was incubated for $1 \mathrm{~h}(6)$.

Fig. 3 shows lipolytic hydrolysis toward various triglycerides. The order of hydrolysis rate was as follows: triolein $>$ tricaprylin $>$ trilaurin $>$ triacetin $>$ tricaproin $>$ tributyrin. Higher lipolytic activity was observed when triglycerides of middle $\left(\mathrm{C}_{8}-\mathrm{C}_{12}\right)$ and long $\left(\mathrm{C}_{18}\right)$ chain fatty acids were used as substrates. This enzyme specificity towards lipids with fatty acid residues of $\mathrm{C}_{8}-\mathrm{C}_{18}$ chain length strongly suggest that the enzyme used in this study showed a true lipase activity $(1,15)$. These results were similar to those presented by lipase from Fusarium oxysporum f. sp. lini (6). On another hand, Rapp (15) found different properties for lipase from Fusarium oxysporum $\mathrm{f}$. $\mathrm{sp}$. vasinfectum, which presented higher hydrolysis activity toward trilaurin at $\mathrm{pH} 5.0$ and $45^{\circ} \mathrm{C}$, and it was not very thermostable.

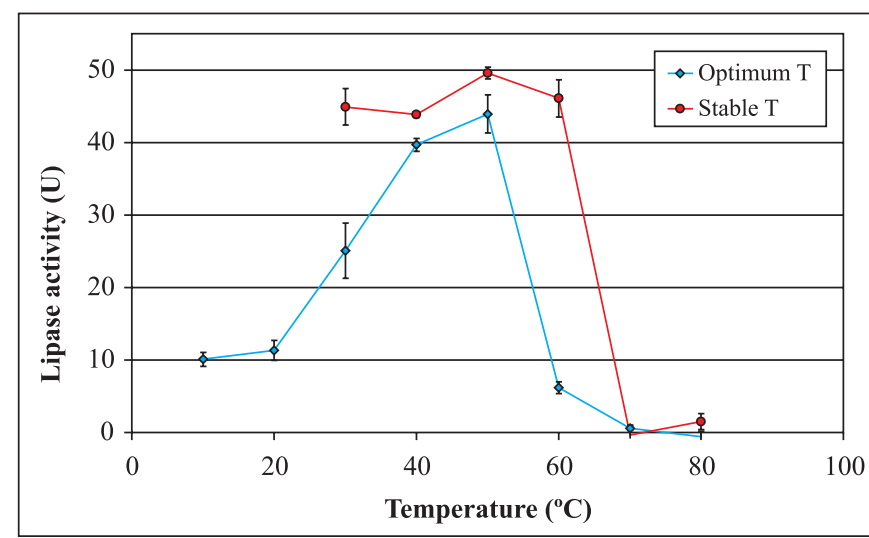

Figure 2. Effects of temperature on alkaline lipase activity and stability. The experiments were performed in triplicate and bars represent the standard derivation.

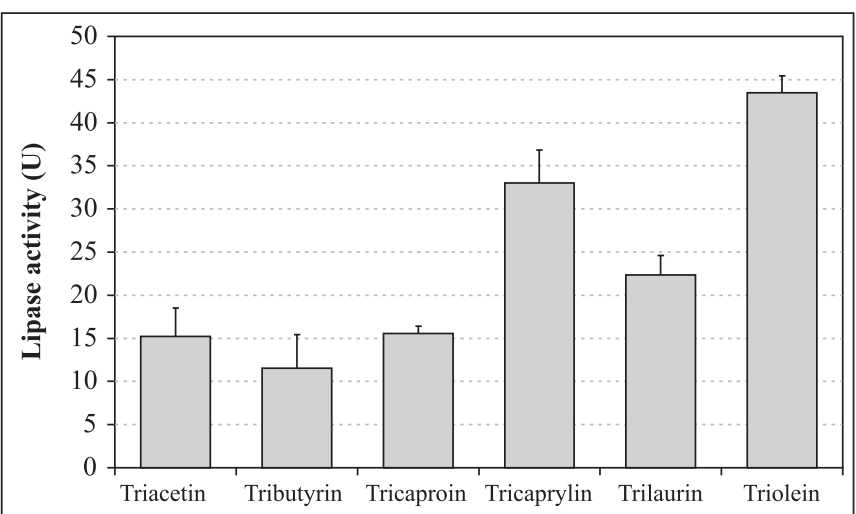

Figure 3. Substrate specificities of alkaline lipase toward several triglycerides. The lipolytic assay was determined at $50^{\circ} \mathrm{C}, \mathrm{pH}$ 8.0, $30 \mathrm{~min}$ incubation. The experiments were performed in triplicate and bars represent the standard derivation.

The enzyme was found to be active on a wide range of natural substrates of either vegetable or animal origin. It hydrolyzed various natural lipids at different rates. This lipase showed major activity on vegetable oil and higher activity on corn oil $125 \%$ compared to olive oil. Lipolytic activity in milk cream was 30\% lower than in olive oil (Fig. 4).

The effects of various surfactants and commercial detergents on the alkaline lipase activity were tested at $10 \%$ and $0.1 \%(\mathrm{w} / \mathrm{v})$. Table 1 shows that the enzyme is stable in both ionic and non-ionic surfactants. Tween 40, Tween 80 and surfactin inhibited up to $30 \%$ lipase activity after $1 \mathrm{~h}$ of incubation at $30^{\circ} \mathrm{C}$. On another hand, Triton X-100 and Triton $\mathrm{X}-114$ showed an activating effect, as showed to lipase from F. oxysporum f. sp. lini (6) using Triton X-100. SDS was a strong inhibitor of Aspergillus caneus (17) and Bacillus 


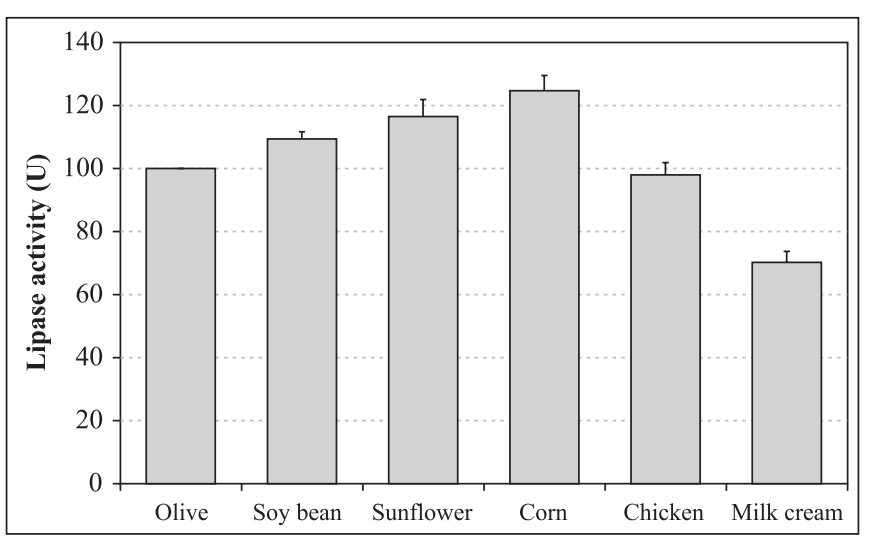

Figure 4. Level of hydrolysis activity from different fatty and oil compared with olive oil (olive oil was taken as $100 \%$ ). The lipolytic assay was determined at $50^{\circ} \mathrm{C}, \mathrm{pH} 8.0,30$ min incubation. The experiments were performed in triplicate and bars represent the standard derivation.

Table 1. Relative lipase activity in presence of surfactants and detergents.

\begin{tabular}{lcc}
\hline Surfactants/detergents & $(\% \mathrm{w} / \mathrm{v})$ & Relative activity $(\%)$ \\
\hline Control $^{\mathrm{a}}$ & 100.00 & \\
Surfactants & & \\
Tween 20 & 10 & 98.75 \\
Tween 40 & 10 & 82.57 \\
Tween 80 & 10 & 69.93 \\
Triton X-100 & 10 & 110.72 \\
Triton X-114 & 10 & 147.39 \\
SDS & 0.1 & 2.39 \\
Surfactin & 1 & 86.86 \\
Commercial detergents & & \\
Omo & 0.1 & 20.19 \\
Vida Plus & 0.1 & 48.91 \\
Tixan & 0.1 & 21.55 \\
Ace & 0.1 & 52.55 \\
Ariel & 0.1 & 34.93 \\
Brilhante & 0.1 & 22.65 \\
Surf & 0.1 & 31.94 \\
Revel & 0.1 & 30.55 \\
\hline
\end{tabular}

All of experiments were done in triplicate and repeated twice;

${ }^{\text {a }}$ No addition of surfactants and detergents; Activity $=732 \mathrm{U} / \mathrm{mL}$ at $40^{\circ} \mathrm{C}$ and $\mathrm{pH} 8.0$.

thermoleovorans CCR11 (3) lipases, causing almost total inhibition of enzyme activity. Pocalyko and Tallman (14) have studied the adverse effect of SDS on the activity and stability of cutinase. They suggested that SDS causes local conformation changes in the active site that result in inhibition, partial reversible unfolding, and subsequent inactivation. Lipases are diverse in their sensitivity to solvents, but there is general agreement that polar water immiscible solvents are more destabilizing than water immiscible solvents (3).

The effects of commercial detergents showed different rates of lipase inhibition at the same conditions as the surfactants, probably because of commercial detergents composition. Rathi et al. (16) studied the effect of commercial detergents as Ariel, Wheel, Nirma, Fena, Surf Ultra, Rin Supreme on lipase activity from Burkholderia cepacia comparing with Lipolase ${ }^{\circledR}$ (Novo Nordisk, Denmark). They found that the lipase from B. cepacia exhibited better resistance to commercial detergents (57-80\% residual activity) than Lipolase ${ }^{\circledR}(40-80 \%$ residual activity) after $1 \mathrm{~h}$ of incubation at $37^{\circ} \mathrm{C}$ and $\mathrm{pH} 11.0$. In the present results, the lipase presented 20-52\% residual activity, less than presented by Lipolase®.

\section{CONCLUSION}

In conclusion, the lipase from $F$. oxysporum has several properties of significant industrial importance, in particular, $\mathrm{pH}$ and temperature stability, $\mathrm{C}_{8}-\mathrm{C}_{18}$ wide specificity. All features presented by this lipase, activity in alkaline $\mathrm{pH}$, high temperature, resistance to many surfactants, and tolerance to commercial detergents, make this enzyme a potential additive for detergent application. Further work to establish what kind of commercial detergent this lipase can be applied and better application conditions are necessary to be carried out.

\section{ACKNOWLEDGEMENTS}

This work was supported by grants from the Conselho Nacional de Desenvolvimento Científico e Tecnológico (CNPq), Brazil and Redes Cooperativas de Pesquisa/Financiadora de Estudos e Projetos (Recope/FINEP), Brazil.

\section{RESUMO}

\section{Caracterização de lipase alcalina de Fusarium oxysporum e ofeito de diferentes surfactantes e detergentes sobre a atividade enzimática}

Atualmente, há uma tendência de utilizar baixas temperaturas em limpeza de lavanderia por razões ambientais e econômicas, situações estas que tornam indispensáveis o uso de enzimas em produtos detergentes. Devido às lipases serem excelentes catalisadoras em soluções e em interface água-óleo, elas são potencialmente apropriadas para aplicação na remoção de manchas de gorduras em lavanderia industrial e detergentes domésticos. $\mathrm{O}$ efeito de diferentes detergentes comerciais e surfactantes sobre a atividade enzimática da lipase de Fusarium 
oxysporum foi observado através de ensaios com $p$ nitrofenilpalmitato ( $p$ NPP). A enzima foi compatível com vários surfactantes iônicos e não-iônicos como também com detergentes comerciais. Atividade lipolítica foi fortemente inibida por Sulfato Dodecil de Sódio (SDS), mas não por Triton X-100 e Triton X-114. As melhores condições de ensaio observadas para esta lipase foram $\mathrm{pH} 8,0 \mathrm{e} 50^{\circ} \mathrm{C}$. A enzima foi estável em $\mathrm{pH}$ alcalino e manteve $93 \%$ da atividade residual durante $1 \mathrm{~h}$ de incubação a $60^{\circ} \mathrm{C}$. A maior atividade lipolítica foi medida com triglicerídeos de ácidos graxos de cadeia média e longa $\left(\mathrm{C}_{8}-\mathrm{C}_{18}\right)$. A especificidade hidrolítica da enzima em vários óleos e gorduras testados foi variável. Todas estas propriedades e sua resistência a vários surfactantes e tolerância a detergentes comerciais fazem desta lipase um aditivo potencial para formulação de detergentes.

Palavras-chaves: Lipase alcalina, Fusarium oxysporum, surfactantes, detergentes

\section{REFERENCES}

1. Arpigny, J.L.; Jaeger, K.-E. Bacterial lipolytic enzymes: classification and properties. Biochem. J., 343: 177-183, 1999.

2. Burkert, J.F.M.; Maugeri, F.; Rodrigues, M.I. Optimization of extracellular lipase production by Geotrichum sp. using factorial design. Bioresour. Technol., 91: 77-84, 2004.

3. Castro-Ochoa, L.D.; Rodríguez-Gómez, C.; Valerio-Alfaro, G.; Ros, R.O. Screening, purification and characterization of the thermoalkalophilic lipase produced by Bacillus thermoleovorans CCR11. Enzyme Microb. Tech., 37: 648-654, 2005.

4. Davranov, K. Microbial lipases in biotechnology (Review). Appl. Biochem. Microbiol., 30(4-5): 427-432, 1994.

5. Helistö, P.; Korpela, T. Effects of detergents on activity of microbial lipases as measured by the nitrophenyl alkanoate esters method. Enzyme Microb. Tech., 23: 113-117, 1998.

6. Hoshino, T.; Sasaki, T.; Watanabe, Y.; Nagasawa, T.; Yamane, T. Purification and some characteristics of extracellular lipase from
Fusarium oxysporum f. sp. lini. Biosci. Biotech. Biochem., 56(4): 660-64, 1992

7. Jaeger, K.-E.; Reetz, M.T. Microbial lipases form versatile tools for biotechnology. TIBTECH, 16: 396-403, 1998.

8. Kulkarni, N.; Gadre, R.V. Production and properties of alkaline, thermophilic lipase from Pseudomonas fluorescens NS2W. J. Ind. Microbiol. Biotechnol., 28: 344-348. 2002.

9. Kumar, S.; Kikon, K.; Upadhyay, A.; Kanwar, S.S.; Gupta, R. Production, purification, and characterization of lipase from thermophilic and alkaliphilic Bacillus coagulans BTS-3. Protein Expr. Purif., 41: 38-44, 2005.

10. Lin, S-F.; Chiou, C.-M.; Tsai, Y.-C. Effect of Triton X-100 on alkaline lipase production by Pseudomonas pseudoalcaligenes F111. Biotechnol. Lett., 17(9): 956-962, 1995.

11. Macedo, G.A.; Park, Y.K.; Pastore, G.M., Partial purification and characterization of na extracellular lipase from a newly isolated strain of Geotrichum sp. Braz. J. Microbiol., 39: 687-692, 1997.

12. Nitschke, M.; Pastore, G.M. Production and properties of a surfactant obtained from Bacillus subtilis grown on cassava wastewater Biotechnol. Research, 97: 336-341, 2006.

13. Pandey, A.; Benjamin, S.; Soccol, C. R.; Nigam, P.; Kriger, N.; Soccol V.T. The realm of microbial lipases in biotechnology. Biotechnol. Appl. Bioc., 29: 119-131, 1999.

14. Pocalyko, D.J.; Tallman, M. Effect of amphipaths on the activity and stability of Fusarium solani pisi cutinase. Enzyme Microb. Tech., 22: 647-651, 1998.

15. Rapp, P. Production, regulation, and some properties of lipase activity from Fusarium oxysporum f. sp. vasinfectum. Enzyme Microb. Tech., 17: 832-838, 1995.

16. Rathi, P.; Saxena, R.K.; Gupta, R. A novel alkaline lipase from Burkholderia cepacia for detergent formulation. Process Biochem. 37: 187-192, 2001.

17. Saxena, R.K.; Davidson, W.S.; Sheoran, A.; Giri, B. Purification and characterization of alkaline thermostable lipase from Aspergillus carneus. Process Biochem., 39: 239-247, 2003.

18. Sharma, R.; Chisti, Y.; Banerjee, U.C. Production, purification, characterization, and applications of lipases. Biotechnol. Adv., 19 627-662, 2001

19. Sharma, R.; Soni, S.K.; Vohra, R.M.; Gupta, L.K.; Gupta, J.K. Purification and characterization of a thermostable alkaline lipase from a new thermophilic Bacillus sp. RSJ-1. Process Biochem., 37 1075-1084, 2002. 